\title{
Colonization in Ghassan Kanfani's Men in the Sun: A Reason for Destruction and Tragedy
}

\author{
Dr. Ghada Fayez Abu-Enein \\ Faculty of Educational Sciences and Arts/ UNRWA University
}

\begin{abstract}
This research delves within the novel Men in the Sun by Ghassan Kanafani, in order to analyze the effect of colonialism on the Palestinian identity. Following what happened to the characters that are presented in the novel after colonization; these characters resemble and present different segments of the Palestinian. This research also includes a deep description of the harsh circumstances that faced each character. Firstly, this research starts with the analysis of each character individually. Secondly, it shows the mutual suffering between all characters. Finally, it ends with the tragic end of all characters. Return to Haifa is also another work for Kanafani. It discusses the conflict that rises within the soul of the colonized as a result of colonialism. This is the focal point for both works. The theory of post-colonialism is the most prominent theory in works of Kanafani. Post-colonial theory describes what happens to the refugees after colonization.
\end{abstract}

Keywords:- Kanafni, Colonialism, Palestinian, Suffering.

\section{INTRODUCTION}

Ghassan Kanafani is considered as one of the most famous Arabian writers and reporters, his literal works were one of the most expressive works that goes in depth in the Arabian and Palestinian culture. Kanafani was born in 1936 in Palestine, he lived in Jaffa until 1948, after that he had to leave Palestine because of the Israeli occupation. In the beginning, he left to Lebanon with his family as refugees then to Syria, he lived and worked in Damascus then in Kuwait. After that, in Beirut he had been martyred with his niece in a car explosion by Israelis spies. Before his assassination, Kanafani published 18 books and wrote hundreds of essays in culture, politics and literature of resistance. After his assassination his works had been republished in Arabic in many editions. Also, his novels, short stories, plays and essays had been collected and published in many volumes. (Kanafani 5,6)

Men in the Sun is one of the novels that Kanafani wrote, he wrote it to be as an example for what happened to the Palestinians after occupation to describe the harshness and injustice that faced them to present for the world a deformed image for Israel. The novel tells a story of four Palestinians who had to leave their home because of Israeli colonization. Abu Qais, Assad and Marwan decided to leave their mother country and go to Kuwait to find a better life that they had to live because of colonization. The novel takes each character alone and starts to analyze and discover all what happened to the character from the beginning to the end then in a certain chapter in the novel
Kanafani moves to represent for us a mutual suffering between all characters because all characters suffered from many problems including the letting of their home, being hit and insulted from a greed fat man and other harsh circumstances.

Aid Ila Hayfa also can be considered as a complement for Men in the Sun. Aid Ila Hayfa is also one of the real novel for Kanafani to describe the circumstances of Palestinians but in another field. Aid Ila Hayfa tells a story of a Palestinian family that abandoned their house in Hayfa because of colonization also, the family had to run away to save the lives of its members, the family succeeded and passed Palestine but later they remembered that they forgot their son whose name was Khaldaun in the house in Palestine. After twenty years the family decided to return and visit Hayfa again and when they entered their village they discovered that everything in their village had completely changed, they discovered later that all the hoses that had been left by its owners had given to the Jews as a bestowal by Israeli government. The family decided to take a tour and they stopped and knocked the door of one house, they felt that the place is so familiar and actually it was their house, an old woman opened the door and allowed them to get into the house. Later, a boy came and saw the family that is consisting of the husband Said and the wife Safiyya, the wife looked to that boy and whispered in the ear of her husband that he is Khaldaun but now his name has changed because he had been left as an infant and as it is known the infant cannot realize the world around him and cannot remember any person because he does not know anyone at all.

Both novels Men in the Sun and Aid Ila Hayfa are related to each other in many faces, in other words they are similar because the revolve around a central axis which is the concentration on following the feelings of sorrow and disappointment that any refugee can suffers from.

Literature of resistance is a common concept between both novels. Literature of resistance can be defined as a movement or instrument to show the enemy that any society does not like to be colonized and it will defeat and resist any force that threat its security or to destroy its identity and integrity. During his works Kanafani wanted to deliver a message to the world saying that there is something called The Right Of Return so he presented and exemplified this concept in his writings and he succeeded because most of his works had been adopted in many areas such as education, politics and other areas. 
Post- colonialism is a specifically postmodern intellectual discourse that consists of reactions to, and analysis of, the cultural legacy of colonialism and imperialism. Post- colonialism is defined in anthropology as the relations between European nations and areas they colonized and once ruled. Post-colonialism comprises a set of theories found amongst history, anthropology, philosophy, linguistics, film, political science, architecture, human geography and sociology.

\section{GOALS OF POST-COLONIALISM}

The ultimate goal of post-colonialism is accounting for and combating the residual effects of colonialism on cultures. It is not simply concerned with salvaging past worlds, but learning how the world can move beyond this period together, towards a place of mutual respect. Postcolonialist thinkers recognize that many of the assumptions which underlie the "logic" of colonialism are still active forces today. A key goal of post-colonial theorists is clearing space for multiple voices. This is especially true of those voices that have been previously silenced by dominant ideologies - subalterns. It is widely recognized within the discourse that this space must first be cleared within academia. Edward Said, in his book Orientalism, provides a clear picture of how the scholars who studied what used to be called the Orient (mostly Asia) disregarded the views of those they actually studied - preferring instead to rely on the intellectual superiority of themselves and their peers. This attitude was forged by European imperialism.

Orientalism is one of the books that Dr Edward Said wrote and it can be defined as a way of seeing that imagines, emphasizes, exaggerates and distorts differences of Arab peoples and cultures as compared to that of Europe and the United States. It often involves seeing Arab culture as exotic, backward, uncivilized, and at times dangerous. Dr Edward Said, in his groundbreaking book, Orientalism, defined it as the acceptance in the West of "the basic distinction between East and West as the starting point for elaborate theories, epics, novels, social descriptions, and political accounts concerning the Orient, its people, customs, 'mind,' destiny and so on."According to Said, Orientalism dates from the period of European Enlightenment and colonization of the Arab World. Orientalism provided a rationalization for European colonialism based on a self-serving history in which "the West" constructed "the East" as extremely different and inferior, and therefore in need of Western intervention or "rescue". ( Reclaiming Identity)

\section{THE INDIVIDUAL ANALYSIS OF THE CHARACTERS}

\section{A. Abu Qais}

At the beginning of the novel Abu Qais rested on the ground, looking at the sky and remembering the accidents that happened with him. Abu Qais had to flee from his village that fill into the hands of Jews to Kuwait during the desert and because of migration he had been drowned by poverty and fight to find a crust of bread. Abu Qais lived in a miserable hut that has given to him by a generous man who allowed him to live there and after a year the man asked Abu Qais to give him half the room because the owner wanted to let other people live with him in the same room and nothing stayed between them except a patched sack. For ten years Abu Qais lived as a beggar, his son Qais should return to the school and soon the other one would grow up but he could not do anything to help them because he does not have nothing. Therefore, death did not become better than his life that he lived, a life that is full of difficulties and waiting for ten years to return to his home and his village.

According to the story of Abu Qais the suffering of Palestinians represented by the miserable situation that he lived, I mean you as a refugee who has faced a lot of difficulties, it is hard to believe that you have to flee from your village and your house to save your life by running away with no money, no stuff, and even with no suitable clothes and no certain destination just to be safe from being killed by Jews. Also, suppose that you were instead of Abu Qais when he went to the shop that belonging to that fat man and bearing on your shoulders all the humiliation, actually this feeling cannot be described. Moreover, the circumstances that you would live in is more miserable like living in a house like a barn with no suitable furniture in addition to the existence of other people living with you in the same place with a weak patch sack that divides the flat. One of the most descriptor quotes that are said by Kanafani on the situation of Abu Qais is:

"A choking lump was tearing his throat. A lump just like the one he had felt when he arrived in Basra and went to the shop belonging to the fat man whose job was smuggling people from Basra to Kuwait. He stood before him, bearing on his shoulders all the humiliation and hope that an old man can carry." ( Kanafani 21 )

As it is noticed, the previous quotation can be considered as strong evidence on what faced Abu Qais during all the novel from the beginning to the end such as going to the shop of the fat man and has been insulted although of his old age. Finally, it is clear that the story of Abu Qais carried a lot of bad situations that any refugee can face during his try to escape from all what happened to him and trying to find a better life even though he is an old man. 


\section{B. Assad}

The suffering of Assad starts after leaving Palestine to find another place to live, so he went to Amman then to Iraq because he wanted to go to the shop of the fat man, he was taken to Iraq by a man called Abul-Abd. To smuggle him to Iraq Abul-Abd asked Assad to pay twenty dinars and because of this exploitation Assad had to borrow fifty dinars from his uncle because his uncle wanted him to go and find a better life in Kuwait and earn money then back to marry his daughter Nada. Abul-Abd followed the policy of intimidation, he told Assad that if he did not pay the agreed amount he would be arrested by saying some words to persuade him. "I'll save your life for twenty dinars. Do you think you'll spend your life here in hiding? Tomorrow they'll arrest you." ( Kanafani 26 ) So the policy of intimidation is clear, Abul-abd is a clever man he exploited the situation of Assad and absolutely he told himself that Assad is horrified because he had been smuggled in an illegal way and he wanted to get rid of this catastrophe so I will continue to exploit the situation of Assad to achieve my goals. So the previous quotation describes another face of colonization's benefits is that to be worry and horrified and not wish to be caught or arrested.

In addition to suffering from the continuous travelling and borrowing money Assad had to walk around an area called $\mathrm{H} 4$ to meet Abul-Abd on the other side, Abul-Abd promised Assad that he will meet him on the other side after the $\mathrm{H} 4$ and Assad trusted him but his trust was not in its place, Assad got out from the truck and walked for four hours around the $\mathrm{H} 4$ under the direct hot sun light to avoid the guards on the borders and he was thinking that if he would be arrested does his situation would be better than now?

After all the circumstances that Assad faced, he can be considered as the character who has faced the most harsh circumstances, in other words his suffering did not stop on that border in which he faced the harshness of the desert at the daytime but in addition he had to face the same circumstances but at the night because Abul-Abd did not levy his promise so he did not return to take Assad after walking around the $\mathrm{H} 4$.

After a long journey that took four hours and tasting treason from his close friend, Assad was left at the desert in the cold with nothing to make him feeling warm, he saw a car coming towards him, he waved to that car and found a foreign man with his wife, he had no option except telling them his story to make them delivering him to an area called Baaquba. After seeing his pathetic situation the foreign man coveted him and allowed him to get into his car, Assad was trembling but he was not know if he is trembling because of the desert cold, or from fear, or exhaustion. After a little period of time the foreign man asked Assad if he could drive the car after taking a little of rest, so Assad agreed and while they are crossing the desert Assad was so confused, he could not realize what is happening around him.
At the end Assad got rid of the dilemma and he could to arrive at the shop of the fat man, the fat man noticed that Assad might be ill so the fat man asked him to call a doctor but Assad refused and asked the fat man when the journey will, the fat man answered him when the number of the group that wants to migrate to Kuwait has become ten and they can start their journey during two days but at the end of their dialogue and before Assad goes he heard the fat man mumbling some words that made him worry. "But take care the rats don't eat you before you set out." (Kanafani 40)

In fact the previous quotation implies to many meanings but the most two appeared meanings that could be clear are deception and irony. Firstly, in an ironic point of view, it can be explained that the fat was making fun of the young age of Assad and he cannot protect himself from any danger that threats him. Secondly, in a deceptive point of view, we can point to the greed of the fat man, he took fifteen dinars from Assad although smuggling needs just five or ten dinars to be in Kuwait.

\section{Marwan}

Before Marwan goes to the shop of the fat man he wrote a letter to his divorced mother, his father divorced his mother and she had four children, he does not want to hate his father but he want know why did his father do such behavior, then he answered himself that all of that bad things happened because of the lack of money which was sent by his brother Zakaria. Zakaria was the only person who sends money from Kuwait to the family for ten years, he was sending two hundred rupees every month so his father wanted to settle down in his old age. Also, his father wanted to marry because Zakaria was taking care of everything that relates to money and spending. Marwan's father had a lot of justifications to marry Shafiqa and one of these justification is that Shafiqa had a hose consisted of three rooms built from cement and the house of Marwan's mother was built from clay.

Marwan was living in a hotel and after he wrote the letter to his mother he went to the shop of the fat man, the fat man was greed and he wanted to take fifteen dinars, Marwan tried to convince the fat man to take only five dinars therefore he threatened the fat man if he did not agree he will denounce him to the police, the fat man stood and came in front of Marwan and slapped him on his check because of this threatening, Marwan could not feel in his face, he got out from the shop and all threads of hope had been cut.

On the street Marwan met a man called Abul Khaizuran, he offered to smuggle Marwan to Kuwait and take just five dinars because Marwan did not have anything except the five dinars. 
Before he travels, Marwan went to the house of his father which he was live in with Shafiqa, Shafiqa told Marwan that she offered his mother to come and live with them but she refused and before Marwan leaves his father gave him ten dinars hoping to help him until he arrives to Kuwait.

Mostly, if we want to discuss the suffering of Marwan during the accidents, we will find a lot of faces that exemplify that suffering. Firstly, his family had been separated. For example, Marwan lived in an old hotel, his brother Zakaria abandoned them and travelled to Kuwait and he was sending money to the family but after a period of time he stopped to contact them because he maybe got married, his father divorced his mother and married another handicap woman because she had a good house. Secondly, Marwan had to leave the school following the order of his brother to help their family and spend on them. In my own opinion it a kind of injustice that a guy like Marwan has to leave school to help his family, I mean the education is one of the most important rights that should be given to any child so it is not fair to prevent any human from his basic rights.

\section{MUTUAL SUFFERING BETWEEN ALL CHARACTERS DURING THEIR JOURNEY}

This kind of suffering starts when the three men got into the tank of Abul Khaizuran, the three men agreed with each other to relay in sitting beside the seat of the driver, Marwan was the first one and Assad and Abu Qais were on the back of the tank, the sun was so hot, it was pouring its inferno down on them. After that, before they arrive to borders they had been told that they had to get into the hot tank that is similar to the hell. During the sitting of Marwan beside Abul Khaizuran, Marwan heard some stories that could make the body shuddering, he heard a story tells about some people who died and became skeletons during their attempt to cross the desert, this is another kind of suffering, the suffering until death. After a period they arrived to the borders, Abul Khaizuran asked the three men to take off their shirts and shoes and to held the girders that were inside tank, Abul Khaizuran closed the tank and jumped quickly into the cabinet, he tried to drive as fast as he can and after they arrived to the top of the hill Abul Khaizuran stopped the vehicle and climbed to open the tank, he pulled Marwan firstly then Abu Qais and finally Assad climbed quickly alone, the three men were in a bad situation they could not move, they could not talk and even they could not open their eyes but this was not the end of their journey, they had to get into the tank again to arrive finally to Kuwait. After they took some rest they went back to the tank, Abul Khaizuran closed the tank again and turned the engine and drove the truck as an arrow that cuts anything in front of it.

\section{THE TRAGIC END OF THE THREE MEN}

After a speed driving for one minute and half Abul Khaizuran arrived and drove his lorry through the big gate and hurried up the steps quickly to the room of officials because he wanted to complete all entrance requirements. The fat official was knowing Abul Khaizuran very well, he became worry because of the glances of the officials towards him but he did not care, he pushed the papers on the table and asked the official to complete the procedures but the official refused to do that and he started to waste time by asking Abul Khaizuran some questions that were unnecessary about his absence but Abul Khaizuran tried to avoid those questions and asking him again to complete the transaction. and after a long effort the fat official signed the papers then Abul Khaizuran moved quickly to the second room and took less than a minute and after finishing everything he drove his lorry like a missile trying to find a place in which he can open the big tank and release the three men. Finally, Abul Khaizuran stopped his lorry which was like a ball of fire that will burn soon, Abul Khaizuran opened the door while his lower lip was trembling, he shouted for the first time by saying "Assad" ( Kanafani 118 ) but the sound came back to him, he decided to slid down inside the tank which was very dark, the yellow light fell into the depth and showed a chest covered with thick gray hair, Abul Khaizuran put his ear on that chest the body was cold, he moved to the back and found the other body was still holding on to the mental support and when his hand touched the face, it fell into a mouth open as wide as it could go.

After the darkness fell Abul Khaizuran drove his car away from the city that was full of lights to a sandy road, he told himself in the beginning throw their bodies on the sand but he changed his mind when he realized that their bodies will become as a food for birds and beasts of prey, he spent a hard effort to pick the dead bodies but before burring them he started to ask himself by saying: "Why did not they knock on the sides of the tank? Why? Why? Why? ( Kanafani 127 ) A suggested answer could be is that they did not knock on the sides of the tank because they did not want to be arrested because they were trying to entre Kuwait illegally, they did not want to return to that miserable life that they lived, they left their homes, their families and everything hoping to go to Kuwait and hoping to find a better life.

This was not good ending for people such Abu Qais, Marwan and Assad, all of them wanted to live a life like a human, they left their mother country because of the savage Israeli occupation in addition to the ignorance of their issue by the whole world. Do they have to die like this way? This was one kind of injustice that faced Palestinians until this day and no one should forget the Palestinian issue and the right of return.

To support the idea of Palestinian people suffering, we have to mention the other work of Kanafani which is Aid Ila Hayfa and exemplify how did they suffer. Aid Ila Hayfa presents a miserable scene of a mother who lost her 
infant by forgetting him in their house during their attempt to escape from death, it is an unimaginable feeling for any mother to lose her young infant and remember him after a long time again, some mothers feel in loneliness when her child goes to school so what will be the feeling of a woman such Safiyya ? Actually, it is an expressive question that represents a complete description of Safiyya' s situation, in some cases she had to accept the harsh reality that she lost her infant and she had to consider that he died and has to forgotten and there is no mother wants to be instead of Safiyya and suffer as she suffered.

\section{CONCLUSION}

To be honest, and after a long and deep study in the works of Kanafani, no one likes to be colonized because colonization is inhuman, it is hell in its most horrible images, the colonized had to suffer, he had to live outside of his home with no basic requirements and be as a beggar who fights to find a crust of bred. In fact, it is not a life that any person would like to live with no independence. Therefore, all the world has to know the feeling of refugees specifically the Palestinians because they suffered twice in 1948 and 1967 and are still suffering until now, this issue cannot because this issue is not modern it is the oldest issue in this world and it should be put on the top of priority list as one of the most important issues in the world.

\section{REFERENCES}

[1]. Kanafani, Ghassan. Men in the Sun. Al-Kaliobeya: .Dar AL-Watan, 2016. Print.

[2]. "Dismantling Arab Stereotypes". Reclaiming Identity. 2011, 26 Jan 2019 http://www.academicroom.com/topics/what-ispostcolonialism>

[3]. " Postcolonialism". Academic Room. 2013, 26 Jan $2019<\mathrm{http} / / / \mathrm{www}$.academicroom.com/topics/what-ispostcolonialism

[4]. Kanafani, Ghassan. Aid Ila Hayfa. Al-Kaliobeya: Dar Al-Watan, 2016. Print. 